\title{
The Influence of the Revolutionary Changes on Crime and Punishment in Russia
}

\author{
L. V. Kangaspuro
}

For citation: Kangaspuro L. V. The Influence of the Revolutionary Changes on Crime and Punishment in Russia. Vestnik of Saint Petersburg University. History, 2018, vol. 63, issue 3, pp. 763-770. https://doi. org/10.21638/11701/spbu02.2018.306

This article discusses the punitive policy of the Russian Tsarist government in the early $20^{\text {th }}$ century as a result of the confrontation between the authorities and the revolutionary forces. Following Michel Foucault's argument, the starting point of this study is that the prison reflects the society and the changes within it. Authoritarianism in late imperial society was not left unchallenged. In the course of the Great Reforms of Alexander II, the prison reform played an important role. The reduction of the number of prisoners and the gradual improvement in the conditions of their detention was interrupted by events that began during the First Russian Revolution of 1905. Under its shadow, the revolutionary movement awoke and activated all kind of crime. The result was a large increase in the number of inmates in Russian prisons. However, a series of unfortunate circumstances, such as an epidemic, the First World War and the last two of the revolutions finally undermined the Russian penitentiary system that was still in the making. The paper applies a holistic approach to the Russian penitentiary system. It utilizes a broad range of sources ranging from legislator memorandums and reports of officials of the Tsarist prison administration to expert opinions published in special journals. It also uses statistical data for quantitative analysis to contextualize separate features in the prison system. Analysis of not only historical and political development in the late Imperial Russia but also of philosophical and legal concepts makes this research a multidisciplinary study.

Keywords: Late Russian Empire, revolutionary changes of 1905-1917, prison, punitive policy.

\section{Влияние революционных перемен на преступление и наказание в России}

\section{Л.В.Кангаспуро}

Для цитирования: Kangaspuro L. V. The Influence of the Revolutionary Changes on Crime and Punishment in Russia // Вестник Санкт-Петербургского университета. История. 2018. Т. 63. Вып. 3. C. 763-770. https://doi.org/10.21638/11701/spbu02.2018.306

В этой статье рассматривается карательная политика российского правительства в начале XX века как результат противостояния между ним и революционными силами. Следуя выводам Мишеля Фуко, отправной точкой этого исследования является ут-

Larisa V. Kangaspuro - PhD, University of Helsinki, P.O.Box 2400014 University of Helsinki, Finland, larisa.kangaspuro@helsinki.fi

Лариса Викторовна Кангаспуро - канд. ист. наук, Хельсинкский университет, Финляндия, 00014, larisa.kangaspuro@helsinki.fi

This work was supported by the Academy of Finland, grant No. 311205

(c) Санкт-Петербургский государственный университет, 2018 
верждение, что тюрьма отражает общество и изменения внутри него. Авторитаризм в конце имперского общества не был абсолютным и безответным. В череде Великих реформ Александра Второго тюремная реформа сыграла заметную роль. Постепенное уменьшение числа заключенных и улучшение условий их содержания было прервано событиями, начавшимися во время Первой русской революции 1905 г. Революционное движение, разбудило преступность, которая активизировалась под ее тенью. Результатом стало резкое увеличение количества заключенных в русских тюрьмах. Правительство предпринимало попытки к стабилизации ситуации в тюрьмах, но череда неудачно сложившихся обстоятельств, эпидемии, Первая мировая война и две последние революции окончательно сломали еще не сложившуюся российскую пенитенциарную систему. В исследовании применяется целостный подход к российской пенитенциарной системе. Используется широкий спектр источников, начиная от меморандумов законодателей и отчетов официальных лиц царской тюремной администрации до мнения экспертов, опубликованных в специальных журналах. Используя статистические данные, автор проводит количественный анализ и раскрывает отдельные особенности функционирования тюремной системы. Статья представляет собой междисциплинарное исследование, в котором рассматривается не только историческое и политическое развитие пенитенциарной системы в поздней имперской России, но и связанные с данной проблематикой философские и правовые концепции.

Ключевые слова: поздняя Российская империя, революционные перемены 1905-1917, тюрьма, карательная политика.

\section{Introduction}

Since Imperial times until today, the institution and idea of prison have held Russian cultural imagination in its grip. The "prison question" is important both for the ones who undergo punishment and for the larger society. The answers to this question have proved to be all but easy.

At the current stage, Russia is willing to forget the defects of the Soviet penitentiary system. It has turned its attention to the experiences of the past - how the penitentiary idea was developed in the Russian Empire on the one hand, and what the experiences from the Western penitentiary system were about 150 years ago, on the other.

The modern prison reform in Russia, which is designed to be completed by 2020 , has already shown good results. Since the beginning of the $21^{\text {st }}$ century (the largest number of prisoners - nearly two million people - was recorded in 2000), the number of prisoners has been significantly reduced through humanization of punishments. In addition, by the end of 2017, the number of prisoners in Russian penal colonies had become less than half a million people ${ }^{1}$.

This paper examines the attitudes of Imperial Russian society to the penitentiary system, which at the time covered not only different types of prisons (tyurma), but also penal labor (katorga) and exile (ssylka). Since the last two institutions worked under special legislation, supervisory authority and funding, they need to be studied separately. The imperial colonial policy also had a great impact on the issue.

The attention here is paid to the changes within Russian state and society that influenced the prison affairs in practice, and to the larger prison question in general. I track down the historical turning points from the 1860's reforms via revolutionary extremism

${ }^{1}$ Chislo zakliuchennykh $\mathrm{v}$ rossiiskikh koloniiakh snizilos' do polumilliona chelovek. TASS informatsionnoe agentstvo. Obshchestvo. URL: http://tass.ru/obschestvo/4839233 (accessed 25.05.2018). 
until the revolutionary changes of 1917. I also compare the different conditions of detention of the convicted "politicals" (political prisoners) and ordinary criminals, and their respective treatment in public discussion.

The starting point of this study is that the prison reflects the society and the changes within it. Following Michel Foucault's argument, the prison contains all the mechanisms that are already present in the body of society. Russian prison system is a revealing and optimal example on how to investigate this question since the essential function of the prison is is to be an extreme institution for converting an individual. In principle, Russian prison provided complete power over its prisoners, imposing compulsory education and total control over the corrective discipline. The isolation of prisoners guaranteed the most effective impact of Tsarist power. The prison defined also the diseases of society.

\section{Russian penitentiary system on the eve of the First Russian Revolution}

The latter part of the $19^{\text {th }}$ century witnessed both internal changes within the Russian penitentiary system and a growing interest of the larger public in the prison question. The discussions over the matter that lasted several decades offer many examples of the interaction between the Tsarist regime and the civil society. Religious, academic and other organizations discussed the prison question and tried to improve the well-being of the convicted.

In the late Tsarist Russia, the Main Prison Administration was part of the Ministry of Internal Affairs until 1895, when the Ministry of Justice started to manage prisons in a more centralized way. The vast heterogeneity of the empire worked against the efforts of the imperial government to standardize Russian penal institutions and practices. Ever since the judicial reform of 1864 , when the corporal punishment was abolished, the prison had become the most widespread establishment for serving punishment.

In the prison reform of 1879, the Tsarist government took into account experiences of the Western penitentiary system, which was based on correctional rehabilitation in solitary confinement. By the end of the century, this Western experience was presented to Russian society as a superior model. Yet, not everyone shared this view. Within the civil society, the issue of penal policy was a factor that divided the Russian public almost along the lines of the "Westerners against the Slavophiles" divide. The conservatives did not agree that the Western model was truly something to be imitated. Despite some opposition, the criminal code adopted in 1903 stated that prisoners, as well as prisoners under investigation, should be held in solitary confinement, albeit in the absence of a sufficient number of single cells, they could be held in common cells.

At the same time, a completely new kind of scholarship on penitentiary questions, tyur'movedenie, started to develop. A famous Russian criminologist I. Ja. Fojnickij started giving a special course (tyur'movedenie) at the Faculty of Law in St. Petersburg University since $1873^{2}$. Furthermore, Imperial Russia was herself an active participant in the international penitentiary movement. The International Penitentiary Congresses were created to serve as a forum where insights and ideas about new approaches would be shared and where new forms of collaboration were initiated. A good example of this was the inter-

${ }^{2}$ To learn more about this concept see: Foinitskii I.Ia. Kurs tiur'movedeniia (1874-1875). St. Petersburg, 1875; Ugolovnoe pravo. Uchenie o nakazanii: Lektsii chitannye v 1-i polovine 1886 goda. St. Petersburg, 1886; Uchenie o nakazanii v sviazi s tiur'movedeniem. St. Petersburg, 1889. 
national prison congress held in St. Petersburg in 1890. On the whole, by the beginning of the $20^{\text {th }}$ century Russia had a developed penal legislation; the prisons had standardized food allowances; hospitals, schools, libraries and churches were opened; and priests of faiths other than Orthodox were invited to work with the prisoners.

\section{The First Russian Revolution (1905-1907) and its consequences for prisons and prisoners}

Before going deeper into the revolutionary changes within the Russian penitentiary system, it should be noted that the crime rate in the Russian Empire in the early $20^{\text {th }}$ century was lower than in other European countries. For example, it was lower than in England by approximately 1,2 times; lower than in France by 1,9 times; and lower than in Germany by 2,4 times $^{3}$.

During the Revolution of 1905 and its aftermath, within just two and a half years, the legislation, the state system and public consciousness underwent some profound changes. The tremendous growth of the number of prisoners (the number nearly doubled) in Russia after the events of 1905-1907 was not only due to political reasons. The revolution also activated criminals, who took advantage of the weakening of the restrictive forces of the state during the social turmoil. In January 1905 the civil prisons contained 80885 prisoners in all categories. By January 1908, there had been as many as 160025 prisoners ${ }^{4}$.

The government started taking increasingly harsh measures against any kind of revolutionary actions, and revolutionaries, for their part, increased the terror against the authorities. The extreme expression of the authorities' response was seen in 1906 during the 8 months of courts-martial ${ }^{5}$. There was a new martial law that reduced the time of conducting investigative and judicial procedures (including the enforcement of the sentence) to 48 hours. The abolition of military courts increased the use of imprisonment.

In 1906-1908, the revolutionary extremists organized a genuine hunt for the highest officials of the empire. Terror became a nightmare for the authorities, and the officials of the Main Prison Administration were particularly affected.

The Tsarist government sought to justify itself and its severe measures before the international public opinion, intimidating it with the threat of an impending revolution. The official address at the VIII International Prison Congress, held in 1910 in Washington, reported that in 1907, 140 prison officers were killed and 169 injured in Russia ${ }^{6}$. In 1907, the director of the Main Prison Administration A. M. Maksimovskii was killed in his office. Shootings, prison riots, attacks against the prisons and the release of prisoners had a negative influence on the organization of the prison system at the time.

There is a tradition in Russia to consider prison inmates as victims of the government, and there was credible ground for this line of thinking. The rise of the revolutionary movement led to a large number of political prisoners. Since these political prisoners

${ }^{3}$ Kratkii ocherk tiuremnogo ustroistva i meropriiatii v oblasti tiuremnogo dela v Rossii za 19051910 gg. // Zhurnal ministerstva iustitsii. St. Petersburg, 1910. N 7. S. 176.

${ }^{4}$ Otchet po glavnomu Tyuremnomu Upravleniyu za 1908 god. Chast' 1. Ob'yasneniya. St. Petersburg, 1910. P. 35.

${ }^{5}$ Faleev N. I. Shest' mesiatsev voenno-polevoi iustitsii // Byloe. St. Petersburg, 1907. N 2. P. 51.

${ }^{6}$ Otchet po Glavnomu tyuremnomu upravleniiu za 1908 g. Chast' 2. Prilozheniia. St. Petersburg, 1910. P. 107. 
presented upper social classes and, moreover, as many of them came from the ranks of the intelligentsia (whom the authorities respected), the Tsarist authorities offered these "politicals" privileged positions - despite the tightening of the prison regime. At the same time, many researchers have come to the conclusion that revolutionary terrorism was a direct consequence of the tightening of the prison regime. ${ }^{7}$ The harshness of the prison life was also one factor leading to the prison administration suffering more than other groups of Tsarist officials in the terrorist attacks ${ }^{8}$.

Yet, despite the growth of the revolutionary movement, the majority of convicts were still ordinary criminals. According to an approximate calculation of one of the prisoners of the Shlisselburg prison, $60 \%$ of the prisoners were convicted for serious criminal offenses 9 .

The lack of necessary number of places for labour prisons in Siberia forced the Main Prison Administration to transform some regular prisons in the territory of European Russia into convict prisons, known as "Central prisons". They were distinguished by a strict internal routine and special fortification. The first of them to be opened, in 1906, was the Vladimir Central prison, made famous much later by a popular Russian chanson song.

During the years of the revolutionary upheavals, the Russian society was also tied to the prison economically. From 1905 to 1907, twice as much money was spent on the prison than on primary education. For example, in 1905 the total prison budget was 16 million roubles, whereas the budget for primary education was 8 million roubles ${ }^{10}$. Despite the annual increase in the funding of the prison authorities (for example, only in 1908 it was increased by three and a half million roubles) ${ }^{11}$, it was necessary to exceed the existing prison budget by several times due to the arisen needs.

To stabilize the situation, the government took several steps such as the construction of Central prisons, expansion of regular prisons, opening of penal servitude in prisons, etc. However, not all of this led to the desired results.

Despite all the difficulties, the general desire to liberalize the penal system in Russia according to "Western standards" did not fade. In 1909, both the institution of conditional early release of inmates and a new system of juvenile correctional facilities were put into practice.

In 1909-1913, the penitentiary system of the Russian Empire was struck by severe health crises. The overcrowding of prisons, caused by the suppression of the revolution, had aggravated the violent epidemic of typhus that had started in late 1908. By 1910, the

7 To learn more about this concept see: Fuller W. C. (Jr.) Civilians in Russian Military Courts: 18811904 // Russian Review. The Editors and Board of Trustees of the Russian Review. 1982. Vol.41, N 3. P. $288-$ 305. Geifman A. Revoliutsionnyi terror v Rossii, 1894-1917. Moscow, 1997; Ruud Ch. A., Stepanov S. A. Fontanka, 16: Politicheskii sysk pri tsariakh. Moscow, 1993; Petrusenko N. Creating the Revolutionary Heroines. The Case of Female Terrorists of the PSR (Russia, Beginning of the 20th. Century). PhD thesis in History in at Stockholm University. Stockholm. 2017.

8 Kratkii ocherk tiuremnogo ustroistva i meropriiatii v oblasti tiuremnogo dela v Rossii za 19051910 gg. // Zhurnal ministerstva iustitsii. St. Petersburg, 1910. N 7. S. 178.

9 Gernet M.N. Istoriia tsarskoi tiur'my. T.5. 1907-1917. Shlissel'burgskaia katorzhnaia tiur'ma i Orlovskii katorzhnyi tsentral. Moscow, 1956. P. 24.

${ }^{10}$ Gernet M. N. Istoriia tsarskoi tiur'my. T. 4. 1900-1917 gg. Petropavlovskaia krepost'. Moscow, 1954. P. 3-4.

11 Otdel offitsial'nyi // Tiuremnyi Vestnik. Tipografiia Glavnogo tiuremnogo upravleniia. St. Petersburg. 1908. N 6-7. P. 439. 
typhus epidemic had been replaced by cholera ${ }^{12}$. A few years later, the evacuation of prisons from the South-West of Russia during the First World War exacerbated the overcrowding of prisons in Central Russia ${ }^{13}$.

Simultaneously, the larger Russian society was becoming more and more divided on social issues. The representatives of the higher authorities demanded increased repression, whereas the State Duma and the public opinion insisted on a broader democratization of society.

During the years of reaction, the liberal bourgeoisie openly switched into counter-revolutionary positions. In 1909, the most outstanding constitutional democratic (cadet) writers ${ }^{14}$ justified government measures in their collection of essays "Vekhi". These "Vekhists" urged citizens to bless the power of autocracy, which "only with its bayonets and prisons still protects us from the wrath of the people"15.

\section{Post-revolutionary changes of 1917}

The February and the October Revolutions brought about few changes in the organizational structure and the material base of prisons, both of which were largely determined by the system established in Tsarist Russia. The period from February to October 1917 is interesting because the Main Prison Administration worked not under an autocratic regime but under a bourgeois-democratic one established by the Provisional Government. It left the prison system virtually unchanged; only renaming the central authority the Main Detention Facilities Administration ${ }^{16}$. However, the staff of the prison officers was subjected to a serious review to determine its loyalty to the new regime. The dual internal policies of the Provisional Government (reactive pseudo-liberal) led to anarchy, which was very detrimental to the state prison industry on the central and local levels ${ }^{17}$.

After the February Revolution of 1917, the prisons were emptied: the Provisional Government announced a broad amnesty, and there were cases when the crowd released those who had not been amnestied. Even though there were soon new prisoners entering the facilities, the number of prisoners continued to decrease, and in September 1917 there were only 34083 people behind bars ${ }^{18}$.

After the October Revolution, the Ministry of Justice was renamed the People's Commissariat of Justice, and the Central Punitive Department was created within its struc-

12 To learn more about this concept see: Ulyannikova Y. Unstable compromise: the Russian penal system between imperial law and colonial expediency, 1845-1913. PhD thesis, School of Historical Studies, The University of Melbourne, School of Historical Studies, 2010. 228 p.

13 To learn more about this concept see: Orfinskaia (Kangaspuro) L. V. Penitentsiarnye uchrezhdeniia v Ukraine v gody Pervoi mirovoi voiny // Naukovo-istorichni chitannia prisviacheni 140-richchiu z dnia rodzhennia M. S. Grushevs'kogo. 22 grudnia 2006 r. / eds O. A. Yanovs'kii, V. M. Boyko. Nizhin, 2007. P.99117. S.L. Frank.

${ }^{14}$ N. A. Berdiaev, S. N. Bulgakov, M. O. Gershenzon, A.S. Izgoev, B. A. Kistiakovskii, P. B. Struve,

${ }^{15}$ Gershenzon M.O. Tvorcheskoe samosoznanie // Vekhi. Intelligentsiia v Rossii. Sbornik statei. Moscow, 1991. P. 101.

16 Tsirkuliar Glavnogo upravleniia mestami zakliucheniia (GUMZ) N 43 ot 24 maia 1917 g. // Gosudarstvennyi arkhiv Rossiiskoi Federatsii (GARF). F. A-353. Op.1. 1917 g. D.92. L. 47.

17 Jakobson M. Origins Of The Gulag: The Soviet Prison Camp System, 1917-1934. The University Press of Kentucky, 2015. S. 17.

18 Utevskii B. S. Sovetskaia ispravitel'no-trudovaia politika. Moscow, 1934. P. 84. 
tures. In July 1918, it published the "Provisional Instruction of the People's Commissariat of Justice" in order to create a complex system of places of detention. This system was supposed to implement two basic principles of the new prison policy: self-sufficiency (income from the labor of prisoners must cover the government's expenses for the maintenance of places of detention) and complete re-education of prisoners ${ }^{19}$.

In parallel with the activities of the People's Commissariat of Justice, another system started to develop: that of places of detention under the Interim Extraordinary Commission, intended to contain the active political opponents of the new government.

It should be noted that the Tsarist government had subsidized the prison system and not tried to make it self-sustaining ${ }^{20}$, and it did not expect to "correct" all prisoners. We now know the sad consequences of the implementation of the "new prison policy".

\section{Conclusions}

Russian prisons, in general, and Russian penitentiary ideology, in particular, have never been isolated phenomena. Penitentiary reforms in North America and Europe, and discussions concerning them, give us the opportunity to estimate the impact of transnational discussions on the development of the prison system in Russia.

However, the conservatism that prevailed in Tsarist prison politics in the late $19^{\text {th }}$ and early 20th centuries, and the constant shortage of financial resources, did not enable to apply the penitentiary experience of the developed Western countries in full.

Nevertheless, over the years under the Main Prison Administration rule, the organizational and legal bases of activity of the penitentiary system had been developed that would be used by all later political regimes in Russia.

A severe penal crisis caused by the first Russian Revolution made expediency the guiding principle of the penal system throughout the Empire. Extreme overcrowding, infectious diseases and prison violence destroyed the well-being in the prisons that had been achieved, at least to some extent, during the last decades of the Tsarist Empire.

The First World War exacerbated this negative trend even further, making emergency institutions such as forced labour a standard feature of the wartime penal landscape. When the Bolsheviks came to power, they eventually placed forced labour at the core of the Soviet penal system, pushing the idea of expediency to the limit.

\section{References}

Foinitskii I. Ia. Kurs tiur'movedeniia (1874-1875). St. Petersburg, Izd. Stud. Sankt Peterburgskogo Universiteta Press, 1875, 464 p. (In Russian)

Faleev N. I. Shest' mesiatsev voenno-polevoi iustitsii. Byloe. St. Petersburg, 1907, no. 2, pp. 43-70. (In Russian)

Fuller W. C. (Jr.) Civilians in Russian Military Courts: 1881-1904. Russian Review. The Editors and Board of Trustees of the Russian Review. 1982, vol.41, no. 3, pp.288-305.

Geifman A. Revoliutsionnyi terror v Rossii, 1894-1917. Moscow, Kron-Press Publ., 1997. 466 p. (In Russian)

Gernet M.N. Istoriia tsarskoi tiur'my. T.4. 1900-1917 gg. Petropavlovskaia krepost'. Moscow, Gosiurizdat Publ., 1954, 248 p. (In Russian)

19 Vremennaia instruktsiia NKIu (Narkomat iustitsii) // GARF. F. 4042. Op. 8. 1917 D. 1. L. 21.

${ }^{20}$ Biudzhet Rossiiskoi imperii // Ezhegodnik Ministerstva finansov. Vyp. 1916. Petrograd, 1917. P. $93-$ 94. 
Gernet M. N. Istoriia tsarskoi tiur'my. T.5. 1907-1917. Shlissel'burgskaia katorzhnaia tiur'ma i Orlovskii katorzhnyi tsentral. Moscow, Gosiurizdat Publ., 1956, 339 p. (In Russian)

Gershenzon M. O. Tvorcheskoe samosoznanie, Vekhi. Intelligentsiia v Rossii. Sbornik statei. Moscow, Molodaia Gvardia Publ., 1991, pp. 85-108. (In Russian)

Jakobson M. Origins Of The Gulag: The Soviet Prison Camp System, 1917-1934. The University Press of Kentucky, 2015. 192 p.

Kratkii ocherk tiuremnogo ustroistva i meropriiatii v oblasti tiuremnogo dela v Rossii za 1905-1910 gg. Zhurnal ministerstva iustitsii. 1910, no.7, pp. 175-242. (In Russian)

Orfinskaia (Kangaspuro) L. V. Penitentsiarnye uchrezhdeniia v Ukraine v gody Pervoi mirovoi voiny. Naukovo-istorichni chitannia prisviacheni 140-richchiu z dnia narodzhennia M. S. Grushevs'kogo. 22 grudnia 2006 r. Eds. O. A. Yanovs'kii, V.M. Boyko. Nizhin, TOV "Vidavnitstvo" "Aspekt-Poligraf " Publ., 2007, pp. 99-117. (In Russian)

Ruud Ch.A., Stepanov S. A. Fontanka, 16: Politicheskii sysk pri tsariakh. Moscow, Mysl' Publ., 1993, 432 p. (In Russian)

Ulyannikova Y. Unstable compromise: the Russian penal system between imperial law and colonial expediency, 1845-1913. PhD thesis, School of Historical Studies, The University of Melbourne, School of Historical Studies, 2010. 228 p.

Utevskii B.S. Sovetskaia ispravitel'no-trudovaia politika. Moscow, Sovetskoe zakonodatel'stvo Publ., 1934, 253 p. (In Russian)

Received: 22.01 .2018

Accepted: 31.05.2018 